Ehler Voss (Ed.)

Mediality on Trial 


\section{Okkulte Moderne}

Beiträge zur Nichthegemonialen Innovation

Herausgegeben von

Christian Kassung,

Sylvia Paletschek,

Erhard Schüttpelz und

Helmut Zander

\section{Band 2}




\section{Mediality on Trial}

Testing and Contesting Trance and other Media Techniques

Edited by

Ehler Voss

\section{DE GRUYTER \\ OLDENBOURG}


Gedruckt mit Unterstützung der Deutschen Forschungsgemeinschaft.

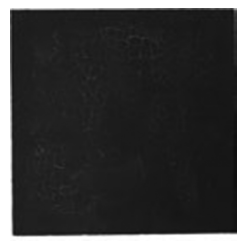

O K K U L T E MODERNE

ISBN 978-3-11-041636-7

e-ISBN (PDF) 978-3-11-041641-1

e-ISBN (EPUB) 978-3-11-041646-6

ISSN 2366-9179

Library of Congress Control Number: 2020936980

\section{Bibliografische Information der Deutschen Nationalbibliothek}

Die Deutsche Nationalbibliothek verzeichnet diese Publikation in der Deutschen Nationalbibliografie; detaillierte bibliografische Daten sind im Internet über http://dnb.dnb.de abrufbar.

(c) 2020 Walter de Gruyter GmbH, Berlin/Boston

Cover image: Some results of a spoon bending party in the San Francisco Bay Area in 2015, photo by Ehler Voss.

Typesetting: Integra Software Services Pvt. Ltd.

Printing and binding: $\mathrm{CPI}$ books $\mathrm{GmbH}$, Leck

www.degruyter.com 
I desired to learn about the shaman, whether it is true / or (whether) it is made up and they pretend to be shamans.

Qā'selīd 
